\title{
一般演題（ポスター） P2-6
}

\section{MRL/Ipr マウスにおける DNA メチル化感受性 転写因子 Kaiso によるカテプシンE (CTSE) の 発現制御}

平松澄恵, 渡部克枝, 浅野洋介, Sonia Zeggar, 宮脇義亜, 勝山恵理, 渡辺晴樹, 松本佳則, 川畑智子, 佐田憲映, 和 田 淳

(岡山大学大学院医歯薬学総合研究科 腎. 免疫. 内分泌代 謝内科学）

【背景】SLE 由来 $\mathrm{T}$ 細胞において新規のメチル化感受性疾 患関連遺伝子を探索するため，SLE モデルマウス MRL/lpr (MRL) 及び対照群 C57BL/6（B6）より脾臓由来 CD4 陽性 T 細胞のメチル化 DNA と mRNA を抽出し, 網羅的シーケ ンス解析によって，MRLにおいてカテプシンE（CTSE） のイントロン 1 領域内の CGCG 配列の DNA 低メチル化 と mRNAの有意な発現六進を確認した。【目的】CTSEの CGCG 配列に結合するメチル化感受性転写因子として Kaiso と HDAC3 に着目し，SLEにおける病態的意義を検証する。 【方法】マウス CD4 陽性 T 細胞および DNA 脱メチル化剂 5-Azacytidine (5-azaC) または histone deacetylase (HDAC) 阻害剂 Trichostatin A（TSA）で処理したマウス T 細胞系培養 細胞（EL-4）を用いて, ChIP-PCRによる Kaiso と HDAC3 の CGCG 配列への結合を確認し, CTSE mRNA 発現量を real-time PCR 法で定量した。 またSLE 初発治療前患者と健 常者の末梢血 CD4 陽性 T 細胞でも同様に検討した。【結果】 ChIP-PCR にてB6に比較し MRL で CGCG 配列への Kaiso と HDAC3 の結合能の低下を確認した。 5-azaC と TSA 処理 後 EL-4 細胞でも有意に Kaiso おうひびHDAC3 の結合能が低 下し,CTSEの mRNA 発現㐫進を認めた。また，健常者に 比較し SLE 患者で末梢血 CD4 陽性 T 細胞の CTSE MRNA の有意な発現上昇を認めた。【結論】SLE 由来 T 細胞では, CTSE イントロン 1 上の CGCG 領域の DNA 脱メチル化によ り, Kaiso および HDAC3の結合が阻害され, CTSEの発現 が立進する可能性が示唆された。 